INTERNATIONAL BULLETIN OF BACTERIOLOGICAL NOMENCLATURE AND TAXONOMY

Volume 4 April 15, $1954 \quad$ No. $2 \quad$ pp. 119-124

\title{
A REVIEW OF NAMES FOR COLIFORM ORGANISMS
}

\author{
S. T. Cowan \\ National Collection of Type Cultures, London, England
}

Nomenclature takes second place to taxonomy; the correct name of an organism can only be determined after its taxonomic position has been settled. There are several nomenclatural problems relating to the members of the family Enterobacteriaceae (the name is used without prejudice) but it is proposed to discuss here only those of the coli-aerogenes groups.

The taxonomic solutions offered by the Enterobacteriaceae Subcommittee (Reports to the Nomenclature Committee presented at the $\mathrm{V}$ and VI International Congresses of Microbiology) divide these organisms into two main groups: (1) the Escherichia group, which contains Bacterium coli commune Escherich, Bacterium freundii Braak, Bacillus alkalescens Andrewes, Bacillus dispar Andrewes, $\overline{\text { Salmonella ballerup }}$ Kauffmann and Móller, Salmonella hormaechei Monteverde, and the Bethesda group of Edwards, West and Bruner; and (2) the Klebsiella group containing Friedlander's Pneumoniecoccus, Klebsiella rhinoscleromatis Trevisan, Bacillus mucosus ozaenae Abel, Bacterium lactis aerogenes Escherich. The reports did not suggest that Bacillus cloacae Jordan should be included in the Klebsiella group, and Kauffmann (1953) has proposed that the separate genus, Cloaca Castellani and Chalmers 1919 should be recognized.

The correct generic and specific names for organisms in these groups are important, not only to those who teach bacteriology or write about bacteria, but to all bacteriologists, and I shall discuss each in turn.

The Escherichia Group (Enterobacteriaceae Subcommittee)

This is the genus Escherichia Castellani and Chalmers 1919. Of its type species, E. coli, the Bergey Manual (1948) lists the following synonyms:

Escherichia coli (Migula) Castellani and Chalmers 1919

Bacterium coli commune Escherich, 1885

Bacillus escherichii Trevisan, 1889

Bacillus coli communis Sternberg, 1893

Bacillus coli Migula, 1895

Bacterium coli Lehmann and Neumann, 1896 
Bacillus coli verus Durham, 1900

Bacillus coli communis verus Durham, 1900

Aerobacter coli Beijerinck, 1900

Bacillus coli-communis Winslow, Kligler and Rothberg, 1919

Bacterium coli-communis Holland, 1920

Colobactrum coli Borman, Stuart and Wheeler, 1944

From this formidable list it appears that the specific epithet, derived from the first binomial, Bacillus escherichii Trevisan, should be escherichii. The generic name will depend on the solution offered to the taxonomic problems. On the assumption that the lactose-fermenting coliforms are divided into two groups, as suggested by the Enterobacteriaciae Subcommittee, and that each group is given generic rank, the generic names to be considered for the Escherichia group are Aerobacter, Escherichia and Colobactrum. (Bacillus and Bacterium have been dealt with in Official Opinions of the Judicial Commission and are not available for the coliform bacteria.)

Aerobacter aerogenes, which was listed by Beijerinck (1900)as the first species of the genus, is generally regarded as the type of Aerobacter. Aerobacter coli was the third species in Beijerinck's list. In its report to the 1953 Congress the Enterobacteriaceae Subcommittee placed Klebsiella pneumoniae and Aerobacter aerogenes together in their Klebsiella group. This makes the generic name Aerobacter a synonym of Klebsiella with another type species. Should Aerobacter again be segregated as a genus, its type species would be $A$. aerogenes. It would probably be unwise for the Judicial Commission, acting on the authority of Rule 15 as amended at the Rome Congress, to conserve the generic name Aerobacter based on another type species. It is wholly unlikely that the Commission would conserve the generic name Aerobacter with Bacterium coli commune Escherich as type species, because the new combinations Aerobacter escherichii or Aerobacter coli would be a constant source of confusion. The only reason for conservation of a name as an exception to the principle of priority is common usage. Such conservation of a commonly used name is only likely to be made when the valid name (i.e. the correct name according to the rules) is one that has never been taken into general use. 
Thus we can reject the generic names Bacterium, Bacillus and Aerobacter for Escherich's Bacterium coli commune, and select Escherichia Castellani and Chalmers, 1919 , which antedates Colobactrum Borman, Stuart and Wheeler, 1944.

Under the rules Escherichia escherichii seems to be the correct name for the type, but it is a combination that apparently has never been used, and to substitute the epithet escherichii for coli would be a source of confusion. Principle 1 (2) of the code allows us "to reject the use of forms and names which may cause error or ambiguity or throw science into confusion" and it is my view that the combination Escherichia escherichii should be barred from use by placing the epithet escherichii in the list of nomina specifica rejicienda, and at the same time conserving the generic name Escherichia C. and C. with the type Escherichia coli (Mi gula) C. and $\mathrm{C}$.

\section{The Klebsiella Group (Enterobacteriaceae Subcommittee)}

In the development of this discussion I am assuming that Bacterium lactis aerogenes Escherich is retainedas a separate species in the same genus as Friedlander's bacillus, and that Bacillus cloacae Jordan is excluded from the Klebsiella group. The generic name will be Klebsiella Trevisan, 1885, which antedates Aerobacter Beijerinck, 1900, and which was approved for conservation at Rome. For Bacterium lactis-aerogenes the Bergey Manual (1948) lists the following synonyms:

Aerobacter aerogenes (Kruse) Beijerinck, 1900

Bacterium lactis aerogenes Escherich, 1885

Bacterium lactis Baginsky, 1888

(not Bacterium lactis, Lister, 1873)

Bacterium aceticum Baginsky, 1888

Bacillus lactantium Trevisan, 1889

Bacillus lactis aerogenes Sternberg, 1893

Bacillus aerogenes Kruse, 1896

(not Bacillus aerogenes Miller, 1886)

Bacterium aerogenes Chester, 1897

(not Bacterium aerogenes Miller, 1886)

Encapsulatus lactis-aerogenes C. and C., 1919

(Encapsulata) Bacillus aerogenes Perkins, 1925

Colobactrum aerogenes Borman, Stuart and Wheeler, 1944 
The first binomial, Bacterium lactis Baginsky is a later homonym of Bacterium lactis Lister, and hence invalid. The epithets of the second and third binomials, Bacterium aceticum Baginsky and Bacillus lactantium Trevisan, have never been taken into general use. To retain the fourth epithet, aerogenes, it will be necessary to have either (a) aerogenes conserved against any earlier name or (b) to place the epithets lactis, aceticum and lactantium in the list of nomina specifica rejicienda. The first alternative is obviously the better in case further research shows an earlier name in some obscure publication.

The following synonyms are listed for Friedlander's bacillus:

Klebsiella pneumoniae (Schroeter) Trevisan, 1887

Bacterium pneumoniae crouposae Zopf, 1885

Klebsiella crouposa Trevisan, 1885

Hyalococcus pneumoniae Schroeter, 1886

Bacillus pneumoniae Flügge, 1886

Klebsiella friedlanderi Trevisan, 1889

Bacillus mucosus capsulatus Paulsen, 1893

Bacterium pneumoniae L. and N., 1896

Bacterium pneumonicum Migula, 1900

Bacillus friedlanderi Macé, 1901

Encapsulatus pneumoniae C. and C., 1919

Coccobacillus friedlanderi Neveu-Lamaire, 1921

Proteus pneumoniae Weldin, 1926

Bacterium friedlander Weldin, 1926

Bacillus mucosus-capsulatus Mason and Beattie, 1928

It could be argued that Zopf's name should be retained as it is binomial, Bacterium pneumoniae-crouposae, the bacterium of croupous pneumonia,with a single epithet. If Zopf's name is rejected the earliest binomial was Klebsiella crouposa Trevisan, 1885. Four years later Trevisan himself rejected the epithet crouposa and substituted friedlanderi for

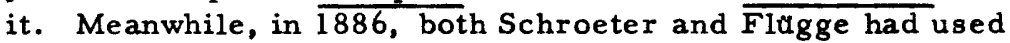
the epithet pneumoniae. Common usage would support both pneumoniae and friedlanderi as specific epithets for the type species, and, as neither is the correct epithet, either could be chosen if an exception is to be mace. It is my view that friedlanderi (or more correctly friedlaenderi) would be the better because such a name would not suggest an association with the disease pneumonia. 


\section{The Cloaca Group}

If a Cloaca group is distinguished a suitable generic name should be found for it. The Bergey Manual lists the following synonyms, but Bacillus and Bacterium are not available. Aerobacter cloacae (Jordan) Bergey, 1923

Bacillus cloacae Jordan, 1890

Bacterium cloacae L. and N., 1896

Bacillus lactis cloacae Conn, Esten and Stocking, 1906 Cloaca cloacae C. and C., 1919 (the Bergey Manual refference should be corrected to Manual of Tropical Medicine, 3 rd ed., p. 958.

The nomenclatural problem here depends on the eventual taxonomic solution. If all motile strains with the IMViC reactions - - + + are to be included in the same genus, conservation of Aerobacter (not Aerobacter Beijerinck) with A. cloacae as the type might be proposed (Rule 15 as amended at Rome would allow this). If this were done the conserved genus would be described as Aerobacter gen. cons. (not Aerobacter Beijerinck), but a genus so named, but not including A. a erogenes (which I have assumed will become Klebsiella aerogenes), would be a source of confusion. The Commission would probably prefer not to conserve Aerobacter with $A$. cloacae as the type, but it might be willing to conserve the generic name next in order of priority, Cloaca Castellani and Chalmers.

\section{Discussion}

We have seen that the Bergey Manual, following common usage, has rejected the earliest specific epithets, escherichii, lactis and crouposa in favor of coli, aerogenes and pneumoniae. Such irregularities should not be condoned unless we are prepared to take action and ask the Judicial Commission to issue Official Opinions on these names. It might be argued that it is unnecessary to conserve these or any other specific names but I suggest that the only way to achieve stability in bacterial nomenclature is to conserve the names of these type species and to designate nomenclatural types. Work is in hand for the selection of a type strain for Bacterium coli commune Escherich, and a directive from the Judicial Commission would set in motion the selection of the other type strains. It is desirable, therefore, that the Judicial Commission should be asked to pass Opinions on the names used for the bacteria we have considered. 
1A. That an opinion be issued on the validity of the generic name Escherichia Castellani and Chalmers, 1919, and that if it is found valid that it be placed in the list of nomina generica conservanda, with the type Escherichia coli (Migula)Castellani and Chalmers, and action taken to designate a type culture of the species $\mathrm{E}$. coli.

1B. That the specific epithet escherichii be placed in the list of epitheta specifica rejicienda.

2A. That an Opinion be issued on the correct name for the type species of the genus Klebsiella Trevisan, 1885, and that action be taken to designate a type culture.

2B. That the specific epithet aerogenes be conserved against all earlier epithets which have been used in synonyms of Bacterium lactis aerogenes Escherich, 1885.

3A. That the Commission should consider whether Aerobacter Beijerinck, 1900, should be placed in the list of nomina generica rejicienda. The Commission should be asked to determine whether a new genus Aerobacter (not A. Beijerinck) should be conserved with the type A. cToacae Jordan, nov. comb., or with a redefined (motile) species $A \cdot$ aerogenes, or whether the genus

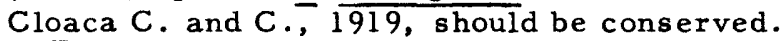

3B. That action be taken to designate a type culture of the species chosen under $3 \mathrm{~A}$, i.e. A. aerogenes (redefined), A. cloacae, or Cloaca cloacae.

\section{REFERENCES}

Beijerinck, 'M.W. Z. Bakt. (II Abt.) 6:193. 1900. Bergey's Manual of Determinative Bacteriology. 6th ed.

Edited by R.S. Breed, E.G.D. Murray and A.P. Hitchens. 1948.

Borman, E.K., C.A. Stuart and K. M. Wheeler. J. Bact. $48: 351.1944$.

Castellani, A. and A.J. Chalmers. Manual of Tropical

Medicine, London: Baillière, Tindall and Cox. 1919.

Enterobacteriaceae Subcommittee Report presented to the

Nomenclature Committee at the $\mathrm{V}$ International Congress for Microbiology, 1950. Int. Bull. Bact. Nomen. Tax.

4:1. $1954 a$.

... VI International Congress for Microbiology, 1953.

Int. Bull. Bact. Nomen. Tax. 4:1. 1954b

Kauffmann, F. Riv. Ist. sieroter. ital. 28:485. 1953. 